\title{
Arsenic trioxide inhibits nuclear receptor function via SEK1/JNK-mediated $\mathrm{RXR} \alpha$ phosphorylation
}

\author{
Koren K. Mann, ${ }^{1}$ Alessandra M.S. Padovani, ${ }^{1}$ Qi Guo, ${ }^{1}$ April L. Colosimo, ${ }^{1}$ Ho-Young Lee, ${ }^{2}$ \\ Jonathan M. Kurie, ${ }^{2}$ and Wilson H. Miller Jr. ${ }^{1}$ \\ ${ }^{1}$ Montréal Centre for Experimental Therapeutics in Cancer, Lady Davis Institute for Medical Research, Sir Mortimer B. Davis Jewish General Hospital, \\ McGill University, Montréal, Québec, Canada. M.D. Anderson Cancer Center, Houston, Texas, USA.
}

\begin{abstract}
We have previously published that 2 proven treatments for acute promyelocytic leukemia, $\mathrm{As}_{2} \mathrm{O}_{3}$ and retinoic acid, can be antagonistic in vitro. We now report that $\mathrm{As}_{2} \mathrm{O}_{3}$ inhibits ligand-induced transcription of the retinoic acid receptor, as well as other nuclear receptors that heterodimerize with the retinoid $\mathrm{X}$ receptor $\alpha$ $(\mathrm{RXR} \alpha) . \mathrm{As}_{2} \mathrm{O}_{3}$ did not inhibit transactivation of the estrogen receptor or the glucocorticoid receptor, which do not heterodimerize with RXR $\alpha$. We further show that $\mathrm{As}_{2} \mathrm{O}_{3}$ inhibits expression of several target genes of $\mathrm{RXR} \alpha$ partners. Phosphorylation of RXR $\alpha$ has been reported to inhibit nuclear receptor signaling, and we show by in vivo labeling and phosphoamino acid detection that $\mathrm{As}_{2} \mathrm{O}_{3}$ phosphorylated $\mathrm{RXR} \alpha$ in the N-terminal $A B C$ region exclusively on serine residues. Consistent with our previous data implying a role for JNK in $\mathrm{As}_{2} \mathrm{O}_{3}$-induced apoptosis, we show that pharmacologic or genetic inhibition of JNK activation decreased $\mathrm{As}_{2} \mathrm{O}_{3}$-induced $\mathrm{RXR} \alpha$ phosphorylation and blocked the effects of $\mathrm{As}_{2} \mathrm{O}_{3}$ on $\mathrm{RXR} \alpha$-mediated transcription. $\mathrm{A}$ mutational analysis indicated that phosphorylation of a specific serine residue, $\mathrm{S} 32$, was primarily responsible for inhibition of RXR $\alpha$-mediated transcription. These data may provide some insight into the rational development of chemotherapeutic combinations involving $\mathrm{As}_{2} \mathrm{O}_{3}$ as well as into molecular mechanisms of arsenicinduced carcinogenesis resulting from environmental exposure.
\end{abstract}

\section{Introduction}

Although arsenic is often associated with environmental contamination, $\mathrm{As}_{2} \mathrm{O}_{3}$ is used clinically to treat cancer. Therapeutic $\mathrm{As}_{2} \mathrm{O}_{3}$ induces differentiation and apoptosis of all-trans retinoic acid-resistant (RA-resistant) acute promyelocytic leukemia (APL) cells in vitro and in patients (1-3). APL cells are characterized by the expression of a unique promyelocytic leukemia/RA receptor $\alpha$ $(\mathrm{PML} / \mathrm{RAR} \alpha)$ fusion protein $(4,5)$, which blocks cells at the promyelocytic stage of differentiation by inhibiting retinoidinduced transcription $(6,7)$. Paradoxically, high doses of RA, a physiologic ligand for RAR $\alpha$, allow APL cells to differentiate in vitro and in vivo (8-11). Administration of RA to patients with APL induces clinical complete remission and, when combined with conventional cytotoxic therapy, provides clear improvements in survival (11-15).

Despite the success of RA in the treatment of APL, many patients relapse with RA-resistant disease. Initially, we investigated in vitro the possibility of using $\mathrm{RA}$ and $\mathrm{As}_{2} \mathrm{O}_{3}$ in a combination therapy. However, we found that $\mathrm{As}_{2} \mathrm{O}_{3}$ and $\mathrm{RA}$ do not act synergistically when used in combination in sensitive APL cells, including NB4 cells and fresh leukemic blasts from patients (1).

\footnotetext{
Nonstandard abbreviations used: AF-1, activation function 1; APL, acute promyelocytic leukemia; CAT, chloramphenicol acetyltransferase; ER, estrogen receptor; LXR, liver $\mathrm{X}$ receptor; MEF, mouse embryo fibroblast; $\mathrm{p}$-, phosphorylated; PML, promyelocytic leukemia; RA, all-trans retinoic acid; RAR, RA receptor; RPA, RNase protection assay; RXR, retinoid X receptor; SEK1, stress-activated protein kinase/extracellular signal-regulated kinase $1 ; \mathrm{SXR}$, steroid and xenobiotic receptor; $\mathrm{T}_{3}$, thyroid hormone; $\mathrm{T}_{3} \mathrm{R}, \mathrm{T}_{3}$ receptor; $\mathrm{VDR}$, vitamin $\mathrm{D} 3$ receptor

Conflict of interest: The authors have declared that no conflict of interest exists.

Citation for this article: J. Clin. Invest. 115:2924-2933 (2005).

doi:10.1172/JCI23628.
}

Rather, $\mathrm{As}_{2} \mathrm{O}_{3}$ antagonizes RA signaling pathways, inhibiting both RAR-dependent transcription and cell differentiation (1). In SCID mice bearing NB4 cells, combined $\mathrm{As}_{2} \mathrm{O}_{3}$ and RA treatment reduced survival, while a sequential treatment increased survival (16). In contrast, there are reports of synergistic or additive differentiation of APL cells in vitro and in animal models (16-19). One study of combination treatment in newly diagnosed patients reported an excellent response rate (20), while in another trial of patients with relapsed APL, the combination of $\mathrm{As}_{2} \mathrm{O}_{3}$ and $\mathrm{RA}$ was not better than $\mathrm{As}_{2} \mathrm{O}_{3}$ alone (21).

RAR $\alpha$ is a member of the nuclear receptor superfamily (reviewed in ref. 22), which is composed of 3 groups: (a) hormone receptors that homodimerize, such as estrogen receptor (ER); (b) receptors that heterodimerize with retinoid $\mathrm{X}$ receptor $\alpha(\mathrm{RXR} \alpha)$, including RA and vitamin D3 receptors (VDRs); and (c) orphan receptors whose ligands are unknown. In general, these receptors are similar in structure and contain similar functional domains: the $\mathrm{A}$ and $\mathrm{B}$ domains, containing the first transactivation domain; the $\mathrm{C}$ domain, responsible for DNA binding and dimerization; the D domain, linking the DNAbinding and ligand-binding domains; and the ligand-binding E domain, containing the second transactivation domain and mediating dimerization and nuclear localization. Some nuclear receptors have an additional $\mathrm{F}$ domain of unknown function. All the nuclear receptors function as ligand-inducible transcription factors via binding to specific DNA response elements, release of corepressors, and recruitment of coactivators (22).

Nuclear receptors are known phosphoproteins, where phosphorylation events may result in either enhanced or inhibited transcriptional activity. EGF activates ER in a ligand-independent manner via MAPK phosphorylation of the activation function 1 

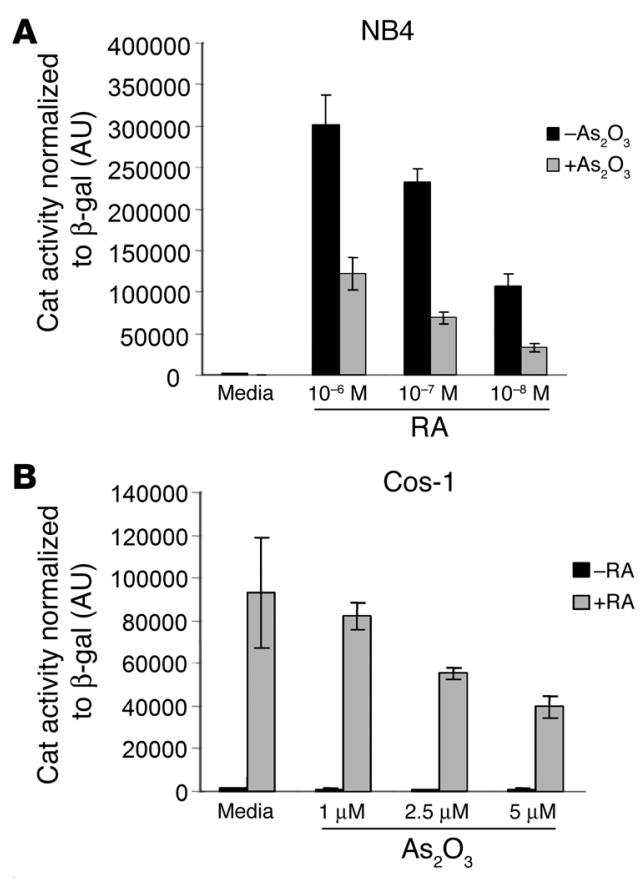

Figure 1

$\mathrm{As}_{2} \mathrm{O}_{3}$ inhibits RA-induced transactivation in both NB4 and Cos-1 cells. NB4 (A) and Cos-1 (B) cells were transiently transfected with reporter plasmid $\beta$ RE-tk-CAT, which contains the retinoid response element from the RAR $\beta$ promoter and the CMV- $\beta$-gal plasmid, to control for transfection efficiency. Cells were subsequently treated with varying combinations of $\mathrm{As}_{2} \mathrm{O}_{3}$ and RA for 48 hours (NB4) or 24 hours (Cos-1). Cells were harvested, and reporter plasmid activity was assessed using CAT and $\beta$-gal assays. Data are representative of 4 separate experiments performed in triplicate and are presented as mean \pm SEM.

(AF-1) domain (23). Phosphorylation of PPAR $\gamma$ by activated MEK significantly inhibits pioglitazone-induced reporter activity (24). RAR $\alpha$ is phosphorylated in the AF-1 domain by CDK7 following binding of transcription factor II $\mathrm{H}$, and this enhances transactivation (25). Phosphorylation of RAR $\alpha$ and $-\gamma$ in both transactivation domains is required for RA- and cAMP-dependent endodermal differentiation (26). RXR $\alpha$ is also a target for phosphorylation, which can regulate the function of heterodimeric binding partners. Phosphorylation of the A domain of RXR $\alpha$ is necessary for RAinduced RAR function in F9 cells (27). Phosphorylation by MAPK and stress-activated protein kinase/extracellular signal-regulated kinase 1 (SEK1) inhibits transactivation by vitamin D3 and RA, respectively $(28,29)$. RXR $\alpha$ is phosphorylated by JNK in the N-terminal, AF-1 domain and by SEK1 in the C-terminal, AF-2 domain (27). In addition, UV irradiation-induced JNK activity is associated with an increase in RXR $\alpha$ phosphorylation, although this may not be linked to altered RA-induced transactivation (30).

Based on the clinical importance of understanding interactions among pathways induced by $\mathrm{As}_{2} \mathrm{O}_{3}$ and RA in APL cells, we have focused investigation on the mechanism by which $\mathrm{As}_{2} \mathrm{O}_{3}$ affects transactivation of nuclear receptors. $\mathrm{As}_{2} \mathrm{O}_{3}$ inhibits the function of several nuclear receptors, specifically those that heterodimerize with RXR $\alpha$. We examined the effects of cotreatment with $\mathrm{As}_{2} \mathrm{O}_{3}$ on induction of several target genes of RXR $\alpha$ partners. We determined that inhibition of RXR $\alpha$-heterodimer transactivation is associated with phosphorylation of the $\mathrm{RXR} \alpha$ protein that requires the SEK1/JNK cascade. We also investigated whether mutation of specific amino acids could inhibit the effects of $\mathrm{As}_{2} \mathrm{O}_{3}$ on ligand-induced transactivation by $\mathrm{RXR} \alpha$ partners.

\section{Results}

To develop an in vitro model, we transiently transfected NB4 cells (a patient-derived APL cell line) with a reporter plasmid containing the RARE from the RAR $\beta$ promoter and subsequently treated the cells with $10^{-6}-10^{-8} \mathrm{M}$ RA alone or in combination with $1 \mu \mathrm{M}$ $\mathrm{As}_{2} \mathrm{O}_{3}$. $\mathrm{As}_{2} \mathrm{O}_{3}$ inhibited the ability of RA to induce transcription of the reporter plasmid at each dose of RA tested (Figure 1A). These data are consistent with our previous results showing that $\mathrm{As}_{2} \mathrm{O}_{3}$ inhibited RA-induced differentiation markers, including CD11b/c cell surface protein expression, NBT expression, and transglutaminase type II activity (1). In order to show that this phenomenon was not specific to APL cells, we transiently transfected Cos- 1 cells with the same reporter plasmid and treated the cells with $10^{-6} \mathrm{M}$ RA and 1-5 $\mu \mathrm{M} \mathrm{As}_{2} \mathrm{O}_{3}$, both alone and in combination (Figure 1B). Again, $\mathrm{As}_{2} \mathrm{O}_{3}$ inhibited retinoid-induced transcription in a dosedependent fashion. We then tested the ability of $\mathrm{As}_{2} \mathrm{O}_{3}$ to inhibit other RARE-containing reporter plasmids. $\mathrm{As}_{2} \mathrm{O}_{3}$ cotreatment also inhibited RA-induced transactivation of a direct repeat with a 5 base pair spacer (DR5) as well as a full-length RAR $\beta$ promoter construct (data not shown).

Next we tested whether $\mathrm{As}_{2} \mathrm{O}_{3}$ inhibition of transcription was specific to RA response elements. To this end, we examined the ability of $\mathrm{As}_{2} \mathrm{O}_{3}$ to inhibit transcriptional activation from response elements of VDR, thyroid hormone $\left(T_{3}\right)$ receptor $\left(T_{3} R\right)$, liver $X$ receptor (LXR), PPAR $\gamma, \mathrm{RXR} \alpha$, steroid and xenobiotic receptor (SXR), ER, and glucocorticoid receptor (GR) (Figure 2). Cos-1 cells were transfected with a corresponding receptor and reporter plasmid pair and subsequently treated with the appropriate ligand alone or in combination with $\mathrm{As}_{2} \mathrm{O}_{3}$. LS180 lung cancer cells were used in the SXR transfections, because the SXRE plasmid was not inducible in Cos- 1 cells. $\mathrm{As}_{2} \mathrm{O}_{3}$ cotreatment inhibited reporter construct activation of all type II nuclear receptors, but not the type 1 hormone receptors. ER and GR activation was unchanged even at the highest dose of $\mathrm{As}_{2} \mathrm{O}_{3}$. Of note, $\mathrm{As}_{2} \mathrm{O}_{3}$ alone decreased basal levels of RXR $\alpha$ heterodimer reporter activity. This suggests that $\mathrm{As}_{2} \mathrm{O}_{3}$ acts to inhibit transcription from only those receptors that heterodimerize with $\mathrm{RXR} \alpha$.

We next determined whether $\mathrm{As}_{2} \mathrm{O}_{3}$ decreased protein levels of RXR $\alpha$ or its heterodimeric binding partner, which might result in a loss of transactivation. Cos- 1 cells were treated for 24 hours, and total cellular protein was isolated. Immunoblotting for total RAR, RXR, VDR, and SXR protein expression revealed no significant decrease in any of the nuclear receptors (Figure 3A). We also investigated the possibility that $\mathrm{As}_{2} \mathrm{O}_{3}$ treatment affects degradation of RXR $\alpha$ caused by 9 -cis RA. Immunoblotting experiments for RXR $\alpha$ showed that 9-cis RA decreased RXR $\alpha$ expression, and this decrease persisted after arsenic treatment (data not shown).

Previous studies have linked inhibition of RXR $\alpha$ heterodimer transactivation to phosphorylation of the RXR $\alpha$. Therefore, we investigated the possibility that $\mathrm{As}_{2} \mathrm{O}_{3}$ also induces RXR $\alpha$ phosphorylation. Cos- 1 cells were transfected with a FLAG-RXR $\alpha$ construct, labeled with [ $\left.{ }^{32} \mathrm{P}\right]$-orthophosphate, and treated with either $5 \mu \mathrm{g} / \mathrm{ml}$ anisomycin as a positive control or varying concentrations of $\mathrm{As}_{2} \mathrm{O}_{3}$ for 3 hours. $\mathrm{RXR} \alpha$ was immunoprecipitated with anti-FLAG antibodies and visualized by 
A
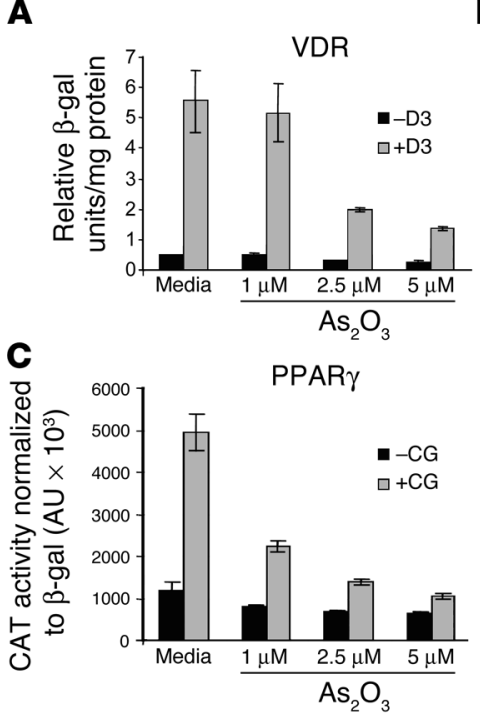

E
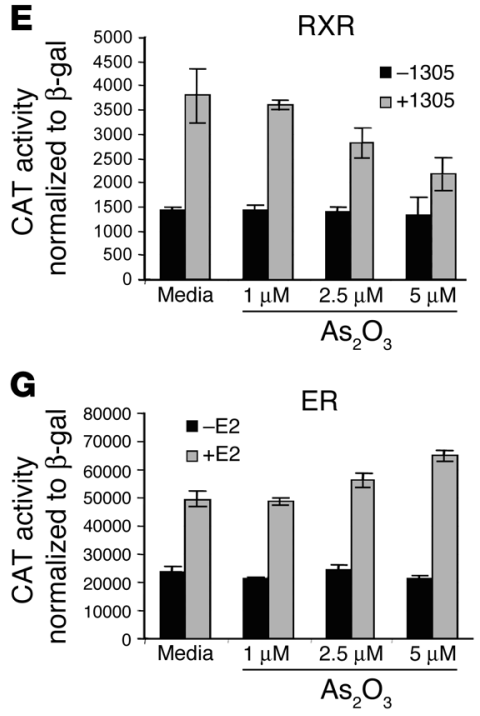

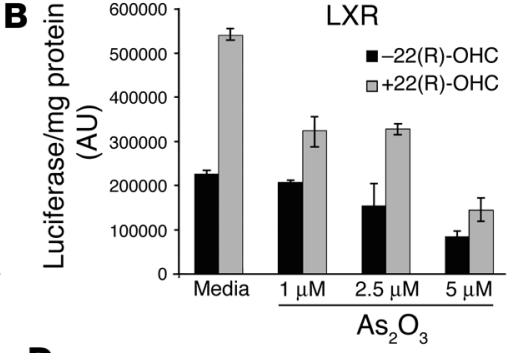

D
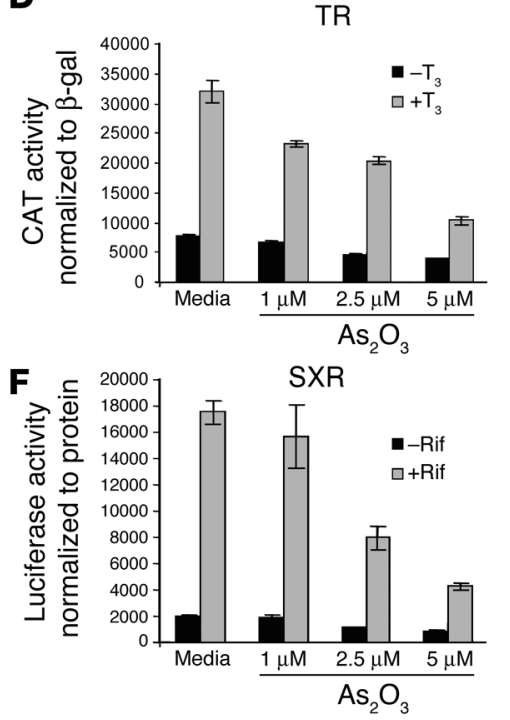

H

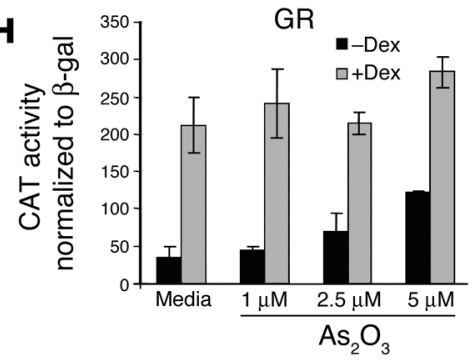

Figure 2

$\mathrm{As}_{2} \mathrm{O}_{3}$ inhibits $\mathrm{RXR}$-binding partner transactivation, but not ER or GR. Cos-1 (A-E, G, and H) or LS180 (F) cells were transiently transfected with receptors and reporter plasmids; pairs are described in Methods. Cells were treated for 24 hours with $10^{-9} \mathrm{M}$ vitamin D3 (A), $2 \mu \mathrm{M}$ 22(R)-hydroxycholesterol [22(R)-OHC] (B), $20 \mu \mathrm{M}$ ciglitazone (CG) (C), 10-7 $\mathrm{M} \mathrm{T}_{3}$ (D), 10-6 M LGD-1305 (1305) (E), $5 \mu \mathrm{M}$ rifampicin (Rif) (F), 10-7 M estradiol (E2) (G), or $10^{-7} \mathrm{M}$ dexamethasone (Dex) $(\mathbf{H})$ in the absence or presence of $1,2.5$, or $5 \mu \mathrm{M} \mathrm{As}_{2} \mathrm{O}_{3}$. Cells were harvested, and the appropriate reporter assays were performed and normalized to $\beta$-gal or protein concentrations. Data are mean \pm SEM of experiments performed in triplicate.
SDS-PAGE and autoradiography. As previously reported $(29,30)$, RXR $\alpha$ was phosphorylated at a constitutive level and was further phosphorylated by anisomycin (Figure 3B). $\mathrm{As}_{2} \mathrm{O}_{3}$ treatment also increased the levels of phosphorylated RXR $\alpha$ in Cos-1 cells in a dose-dependent manner. The levels of transfection were controlled by immunoblotting with anti-FLAG antibody. Densitometry of phosphorylated bands compared with that of anti-FLAG control revealed that $\mathrm{As}_{2} \mathrm{O}_{3}$ treatment causes a 1.74to 2.2-fold increase in phosphorylation when compared with media-treated cells. Of interest, 2 phosphoproteins were coimmunoprecipitated with FLAG-RXR $\alpha$ (Figure 3B). A time course analysis revealed $\mathrm{As}_{2} \mathrm{O}_{3}$-induced phosphorylation of $\mathrm{RXR} \alpha$ as early as 2 hours after treatment (data not shown).

We also determined whether endogenous $\operatorname{RXR} \alpha$ was phosphorylated following $\mathrm{As}_{2} \mathrm{O}_{3}$ treatment. Cos- 1 cells were treated for 3 hours with media or $5 \mu \mathrm{M} \mathrm{As}_{2} \mathrm{O}_{3}$ in the presence of $\left[{ }^{32} \mathrm{P}\right]$-orthophosphate. $\mathrm{RXR} \alpha$ was immunoprecipitated, and the immunoprecipitates were separated by SDS-PAGE and visualized by autoradiography. $\mathrm{As}_{2} \mathrm{O}_{3}$ treatment resulted in increased phosphorylation of RXR $\alpha$ compared with media-treated cells
(Figure 3C), while the levels of total RXR $\alpha$ remained unchanged. Rabbit Ig was used as a negative control to indicate nonspecific bands. These data are consistent with previous data showing that $\mathrm{As}_{2} \mathrm{O}_{3}$ treatment results in a slower-migrating band in immunoblotting experiments (31).

We used $\mathrm{RXR} \alpha$ deletion mutants to investigate which domain of the RXR $\alpha$ protein was phosphorylated after $\mathrm{As}_{2} \mathrm{O}_{3}$ treatment. Cos- 1 cells were transfected with wild-type $\operatorname{RXR} \alpha$, the $A B C$ regions of $R X R \alpha$, or the CDE regions of $R X R \alpha$. In vivo labeling was performed, and the proteins were isolated by immunoprecipitation with anti-FLAG antibodies. Wild-type RXR $\alpha$ phosphorylation as well as phosphorylation of the ABC region was enhanced after treatment with $5 \mu \mathrm{M} \mathrm{As}_{2} \mathrm{O}_{3}$ (Figure 4A). However, the CDE region had a high constitutive level of phosphorylation that remained unchanged after $\mathrm{As}_{2} \mathrm{O}_{3}$ treatment. Densitometry measurements showed a 2.2-fold induction of phosphorylation in the $\mathrm{ABC}$ region compared with a 0.96 -fold change in the $\mathrm{CDE}$ region. The phosphorylation pattern of deletion mutants of the $\mathrm{AB}$ region was similar to that in the $\mathrm{ABC}$ region, and DE was similar to $\mathrm{CDE}$ (data not shown). Mem- 

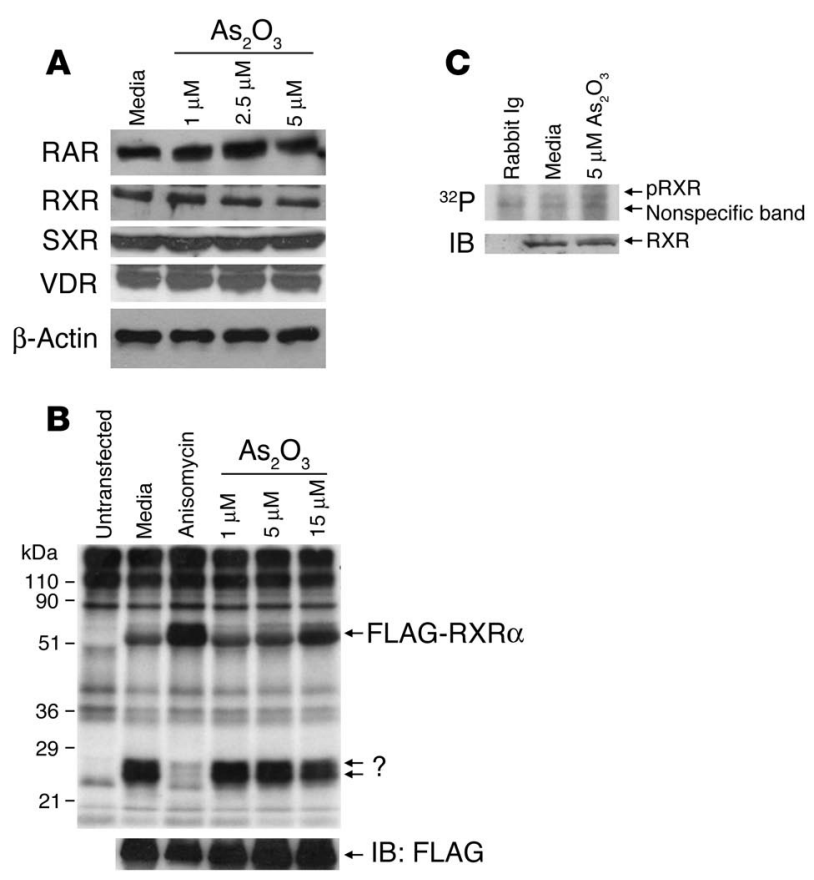

branes were immunoblotted with anti-FLAG antibodies in order to control for equal immunoprecipitation (Figure 4B). In order to define which residues were being phosphorylated, phosphoamino acid analysis was performed on bands corresponding to FLAG-RXR $\alpha$ that were excised from in vivo labeling membranes. Only serine phosphorylation was detected in the bands, even those representing $\mathrm{As}_{2} \mathrm{O}_{3}$-treated samples (Figure 4C). Again, an $\mathrm{As}_{2} \mathrm{O}_{3}$-induced increase was only seen in the construct containing the $\mathrm{ABC}$ region. Together, these data show that $\mathrm{As}_{2} \mathrm{O}_{3}$ increases the serine phosphorylation of RXR $\alpha$ within the $A B C$ region.

Several MAPKs phosphorylate RXR. Our previous studies as well as those from other laboratories have shown that $\mathrm{As}_{2} \mathrm{O}_{3}$ activates MAPK $(28,32,33)$. Specifically, we have previously shown that $\mathrm{As}_{2} \mathrm{O}_{3}$ induces JNK activation in a SEK1-dependent manner (32). Therefore, we postulated that $\mathrm{As}_{2} \mathrm{O}_{3}$-induced phosphorylation of RXR $\alpha$ and decreased function of RXR-containing heterodimers may be a result of these kinases. We used pharmacologic inhibi-

\section{Figure 4}

$\mathrm{As}_{2} \mathrm{O}_{3}$ induces phosphorylation of the RXR $\alpha A B C$ domain. (A) Cos-1 cells were transfected with FLAG-RXR $\alpha$ (WT), FLAG-RXR $\alpha$ ABC $(A B C)$, or FLAG-RXR $\alpha$ CDE (CDE) plasmids. After serum starvation and phosphate starvation, cells were treated with media or $5 \mu \mathrm{M}$ $\mathrm{As}_{2} \mathrm{O}_{3}$ for 3 hours in the presence of $\left.{ }^{32} \mathrm{P}\right]$-orthophosphate. Cell lysates were used to immunoprecipitate FLAG-tagged proteins, and the immunoprecipitates were separated by $10 \%$ SDS-PAGE. Phosphorylated RXR $\alpha$ constructs are indicated by asterisks. (B) The radioactive label on the in vivo labeling blot was allowed to decay and the blot was used in immunoblotting experiments using the anti-FLAG antibody to confirm equal immunoprecipitation of proteins. FLAG$\mathrm{RXR} \alpha$ constructs are indicated by asterisks. (C) Phosphoamino acid analysis was performed on bands from in vivo labeling experiments in Cos-1 cells. After acid hydrolysis and lyophilization, samples were separated on thin-layer chromatography plates along with standards of phosphoamino acids. Plates were exposed to film and followed by ninhydrin staining to visualize the phosphoamino acid positive controls.

\section{Figure 3}

$\mathrm{As}_{2} \mathrm{O}_{3}$ does not alter total nuclear receptor expression, but does induce phosphorylation of $\mathrm{RXR} \alpha$. (A) Cos- 1 cells were treated for 24 hours with media or $1,2.5$, or $5 \mu \mathrm{M} \mathrm{As}_{2} \mathrm{O}_{3}$. Total cellular protein extracts were then used in immunoblotting experiments with antibodies recognizing RAR, RXR, VDR, SXR, or $\beta$-actin. (B) In in vivo labeling experiments, Cos- 1 cells were transfected with $5 \mu \mathrm{g}$ of FLAG-RXR $\alpha$ plasmid, serumstarved overnight, phosphate-starved for 1 hour, and then treated with media, $5 \mu \mathrm{g} / \mathrm{ml}$ anisomycin, or 1,5 , or $15 \mu \mathrm{M} \mathrm{As}{ }_{2} \mathrm{O}_{3}$ for 3 hours in the presence of $\left[{ }^{32} \mathrm{P}\right]$-orthophosphate. Cell lysates were used to immunoprecipitate FLAG-tagged proteins, and the immunoprecipitates were separated by $10 \%$ SDS-PAGE. Immunoblotting for anti-FLAG is shown as a control in lower blot. (C) Cos-1 cells were serum-starved overnight, phosphate-starved for 1 hour, then treated with media or $5 \mu \mathrm{M} \mathrm{As}_{2} \mathrm{O}_{3}$ for 3 hours in the presence of [ $\left.{ }^{32} \mathrm{P}\right]$-orthophosphate. Cell lysates were used to immunoprecipitate endogenous RXR, and the immunoprecipitates were separated by $10 \%$ SDS-PAGE (top). Immunoblotting of Cos-1 whole-cell lysates treated with media or $5 \mu \mathrm{M} \mathrm{As}_{2} \mathrm{O}_{3}$ for 3 hours are shown as a control for changes in total RXR (bottom).

tors of JNK, p38, and MEK/ERK to begin to determine which of these kinases could be involved in the inhibition of nuclear receptor transactivation by $\mathrm{As}_{2} \mathrm{O}_{3}$. Cos- 1 cells were transfected with VDR and the VDRE reporter plasmid and treated with vitamin D3 plus $\mathrm{As}_{2} \mathrm{O}_{3}$ in the presence of kinase inhibitors. As shown in Figure 5A, only the JNK inhibitor SP600125 abrogated the $\mathrm{As}_{2} \mathrm{O}_{3}$ induced decrease in vitamin D3 function. We extended these studies to include RAR $\alpha$ transactivation of the $\beta$ RE-tk-chloramphenicol acetyltransferase ( $\beta$ RE-tk-CAT) reporter plasmid. Our results show that, like vitamin $\mathrm{D} 3$ transactivation, inhibition of RA transactivation by $\mathrm{As}_{2} \mathrm{O}_{3}$ can be reversed by the JNK inhibitor, but not the MEK or p38 inhibitors (Figure 5A). We also utilized mouse embryo fibroblasts (MEFs) deficient in SEK1, an upstream regulator of JNK, to determine whether $\mathrm{As}_{2} \mathrm{O}_{3}$-induced effects on

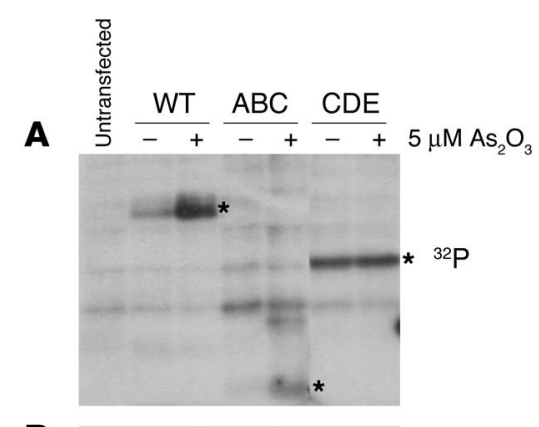

B

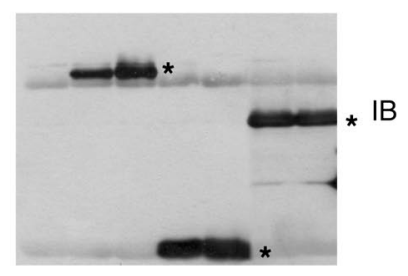

C

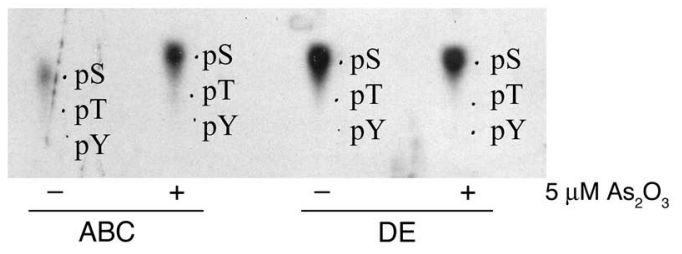




\section{Figure 5}

JNK is involved in inhibition of nuclear receptor transactivation by $\mathrm{As}_{2} \mathrm{O}_{3}$. (A) Cos-1 cells were transfected with either VDR and VDR-tk-LacZ reporter plasmids (left panels) or $\beta$ RE-tk-CAT and CMV- $\beta$-gal reporter plasmids (right panels). Cells were then treated with the appropriate ligand, either $10^{-9} \mathrm{M}$ vitamin D3 (left panels) or $10^{-6} \mathrm{M} \mathrm{RA}$ (right panels), $5 \mu \mathrm{M} \mathrm{As}_{2} \mathrm{O}_{3}$, or ligand plus $\mathrm{As}_{2} \mathrm{O}_{3}$, in the absence or presence of JNK inhibitor SP600125 (SP; $10 \mu \mathrm{M})$, p38 inhibitor SB203580 (SB; $20 \mu \mathrm{M}$ ), or MEK inhibitor PD98059 (PD; $50 \mu \mathrm{M})$. (B and C) SEK1+/+ (B; left), SEK1-/- (B; right), wild-type (C; top left), JNK1/2-/- (C; top right), and SEK1/2-- (C; bottom) MEFs were transiently transfected with VDR and VDR-tk-LacZ plasmids and treated with media, $10^{-9} \mathrm{M}$ vitamin $\mathrm{D} 3$, the indicated concentrations of $\mathrm{As}_{2} \mathrm{O}_{3}$, or vitamin D3 in combination with $\mathrm{As}_{2} \mathrm{O}_{3}$. In $\mathbf{A}-\mathbf{C}$, cells were harvested after 24 hours and cell lysates used in $\beta$-gal assays to determine reporter activity. Values are normalized to protein concentrations. (D) Cos-1 cells were transfected with FLAG$\mathrm{RXR} \alpha$ (top 2 blots) or FLAG-RXR $\alpha$ ABC plasmids (bottom 2 blots). After serum starvation and phosphate starvation, cells were treated with media, $5 \mu \mathrm{M} \mathrm{As}_{2} \mathrm{O}_{3}, 10 \mu \mathrm{M}$ SP600125, or the combination for 3 hours in the presence of [ $\left.{ }^{32} \mathrm{P}\right]$-orthophosphate. Cell lysates were prepared as described in Methods, and immunoblotting was performed using the anti-FLAG antibody to confirm equal immunoprecipitation of proteins.

transactivation were altered. We have shown previously that the cytotoxicity of $\mathrm{As}_{2} \mathrm{O}_{3}$ is significantly inhibited in SEK1-/MEFs (32). Here we transfected both wild-type and knockout MEFs with VDR and the VDRE reporter plasmid and treated them with vitamin D3 in the presence or absence of $\mathrm{As}_{2} \mathrm{O}_{3}$. Inhibition of VDR activity by $\mathrm{As}_{2} \mathrm{O}_{3}$ was significantly less in knockout MEFs compared with wild-type MEFs (Figure 5B), providing further evidence for a role of $\mathrm{SEK} / \mathrm{JNK}$ in the antagonism of nuclear receptor transcriptional activation by $\mathrm{As}_{2} \mathrm{O}_{3}$. These results were confirmed using SEK1/2-/- MEFs (Figure 5C). Furthermore, $\mathrm{As}_{2} \mathrm{O}_{3}$ did not inhibit vitamin D3 transactivation in JNK1/2-/- MEFs that had SEK1/2 activity (34). This suggests that JNK1 and/ or JNK2 may be the kinase that phosphorylates RXR $\alpha$ in a SEK1-dependent fashion.

In an effort to connect $\mathrm{As}_{2} \mathrm{O}_{3}$-induced phosphorylation of RXR $\alpha$ with JNK activity and antagonism of receptor signaling, we examined whether inhibition of JNK activity decreased $\mathrm{As}_{2} \mathrm{O}_{3}$-induced phosphorylation. Cos- 1 cells were transfected with either wild-type or the $\mathrm{RXR} \alpha \mathrm{ABC}$ region, labeled with $\left[{ }^{32} \mathrm{P}\right]$-orthophosphate, and treated with $\mathrm{As}_{2} \mathrm{O}_{3}$ alone or in combination with the JNK inhibitor SP600125. As previously demonstrated, $\mathrm{As}_{2} \mathrm{O}_{3}$ increased phosphorylation of both wild-type RXR $\alpha$ and RXR $\alpha$ ABC (Figure 5D). SP600125 treatment decreased both the constitutive and $\mathrm{As}_{2} \mathrm{O}_{3}$-induced levels of phosphorylation. This reduced level of phosphorylation of the RXR $\alpha$ ABC region suggests that phosphorylation is mediated by both JNK and another kinase not inhibited by SP600125.

To further define the site(s) of phosphorylation in $\mathrm{RXR} \alpha$ required to mediate inhibition by $\mathrm{As}_{2} \mathrm{O}_{3}$ of nuclear receptor signaling, we performed site-directed mutagenesis on all 11 proline-directed serines within the $\mathrm{ABC}$ region (Figure $6 \mathrm{~A})$. We chose these amino acids based on the induction of serine phosphorylation in the phosphoamino acid analysis and the known consensus sequence for targets of JNK phosphorylation. Each
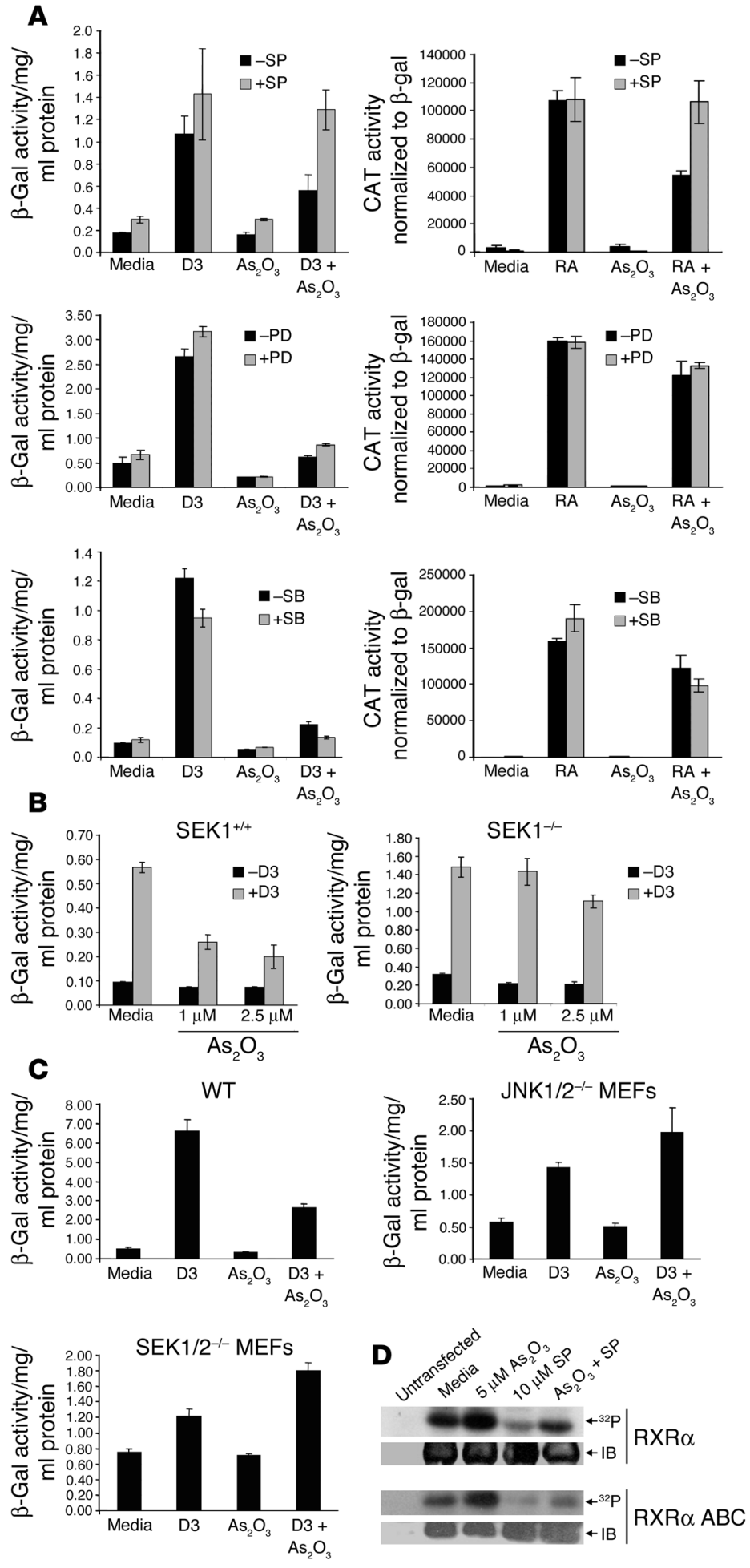

mutated plasmid was then tested to determine whether a specific serine-to-alanine mutation could abrogate inhibition of nuclear receptor function by $\mathrm{As}_{2} \mathrm{O}_{3}$. Cos- 1 cells transfected with wild-type or mutated RXR $\alpha, \beta$ RE-tk-CAT, and CMV- $\beta$-gal plasmids were treated with RA alone or in combination with $\mathrm{As}_{2} \mathrm{O}_{3}$. We found that only the S32A mutation abrogated the ability of $\mathrm{As}_{2} \mathrm{O}_{3}$ to inhibit RA-induced transactivation as well as vitamin D3 trans- 
A
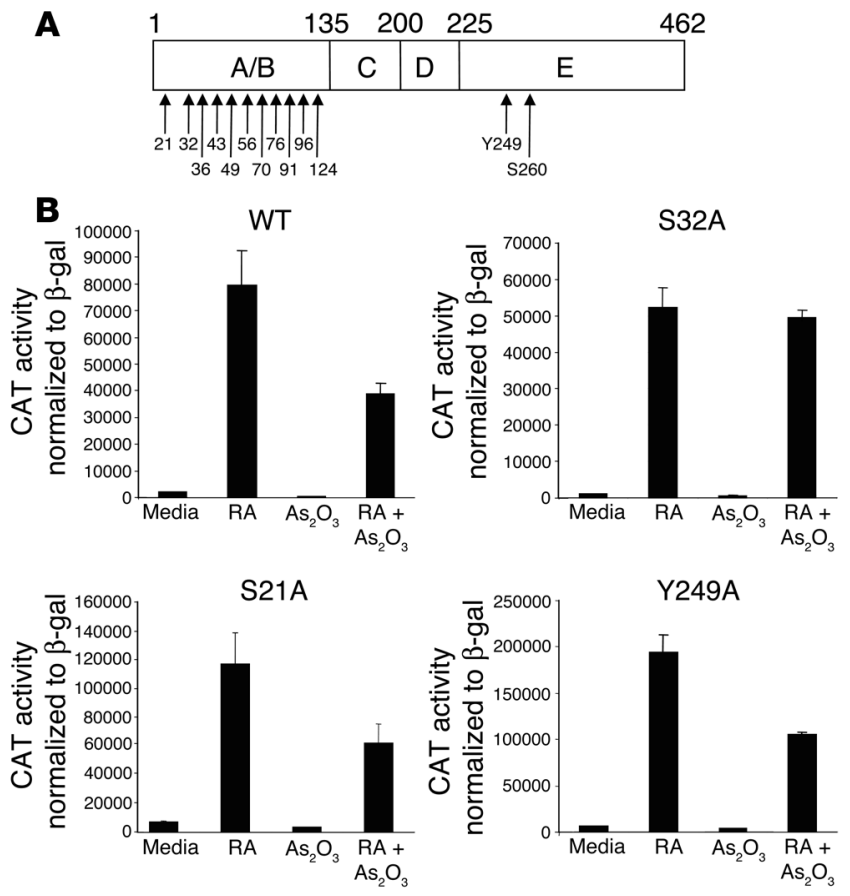

activation (Figure 6B and data not shown). S21A was added as a control mutation of an amino acid known to be phosphorylated by JNK (30). We also tested whether $\mathrm{As}_{2} \mathrm{O}_{3}$-induced phosphorylation of total RXR $\alpha$ or the ABC region of RXR $\alpha$ could be inhibited by mutation of S32A in in vivo labeling experiments. We did not see a difference between S32A-mutated RXR $\alpha$ and wild-type $\mathrm{RXR} \alpha$ phosphorylation following arsenic treatment, but considering the number of amino acids known to be phosphorylated on $\operatorname{RXR} \alpha(26-29)$, this assay may not detect a single amino acid change (data not shown).

Although we did not see an increase in DE-region phosphorylation, the high constitutive level of phosphorylation could mask a change in a single phosphorylation site. Therefore, we also tested mutations in several amino acids in this region

\section{Figure 6}

Only mutation of $\mathrm{S} 32 \mathrm{~A}$ in $\mathrm{RXR} \alpha$ abrogates inhibition of nuclear receptor transactivation by $\mathrm{As}_{2} \mathrm{O}_{3}$. (A) Diagram of $\mathrm{RXR} \alpha$ showing mutated serine residues. (B) Cos-1 cells were transiently transfected with $\beta$ RE-tk-CAT reporter plasmid and wild-type or mutated $\mathrm{RXR} \alpha$ and treated with media, $10^{-6} \mathrm{M} R A, 2.5 \mu \mathrm{M} \mathrm{As}_{2} \mathrm{O}_{3}$, or the combination. Cells were harvested after 24 hours, and cell lysates were used in CAT assays to determine reporter activity. Values are normalized to protein concentrations.

known to cause inhibition of nuclear receptor transactivation. Y249 is the target of SEK1 phosphorylation, which is responsible for the inhibition of RA-induced transactivation by anisomycin (29). S260 is a target for MAPK phosphorylation that causes inhibition of vitamin D3 transcription (28). Neither of these mutations changed the ability of $\mathrm{As}_{2} \mathrm{O}_{3}$ to inhibit RA-induced transactivation (Figure 6B and data not shown).

Our previous work showed that $\mathrm{As}_{2} \mathrm{O}_{3}$ could inhibit downstream targets of RA (1), so we wanted to extend this to downstream targets of other nuclear receptors. ABCA1 is a transporter induced by LXR/RXR heterodimers (35). We treated NB4 cells with 22(R)-hydroxycholesterol and 9-cis RA for 8 hours and immunoblotted cytoplasmic proteins for 2 hours and used total RNA in Northern blots to determine the induction of ABCA1. $A B C A 1$ protein was strongly induced by the combination of LXR and RXR ligands, but not with $\mathrm{As}_{2} \mathrm{O}_{3}$ alone, and the induction by the LXR/RXR combination was decreased by cotreatment with $\mathrm{As}_{2} \mathrm{O}_{3}$ (Figure 7A, top 2 blots). ABCA1 mRNA induction by LXR/RXR ligands mirrored the induction of the protein as did the inhibition by $\mathrm{As}_{2} \mathrm{O}_{3}$ (Figure 7A, bottom 2 blots). In addition, we investigated the effect of $\mathrm{As}_{2} \mathrm{O}_{3}$ on SXR ligand-induced CYP3A4 in HepG2 hepatoma cells. HepG2 cells were treated for 24 hours with media, $50 \mu \mathrm{M}$ rifampicin, $5 \mu \mathrm{M} \mathrm{As}_{2} \mathrm{O}_{3}$, or rifampicin and $\mathrm{As}_{2} \mathrm{O}_{3}$ combined. Microsomes were isolated from the cells and used in Western blots for CYP3A4 expression (Figure 7B). As expected, rifampicin alone increased CYP3A4 expression; however, the combination of $\mathrm{As}_{2} \mathrm{O}_{3}$ with rifampicin blocked this increase. A Ponceau-stained band was included as a loading control for microsomal proteins. Vitamin D3 24-hydroxylase was studied as a VDR target gene. We determined the level of

\section{Figure 7}

Endogenous nuclear receptor target induction is inhibited by $\mathrm{As}_{2} \mathrm{O}_{3}$ cotreatment. (A) NB4 cells were treated for 8 hours with media, $10^{-5} \mathrm{M}$ 9-cis RA plus $4 \mu \mathrm{g} / \mathrm{ml} 22(\mathrm{R})$-hydroxycholesterol, $5 \mu \mathrm{M} \mathrm{As}_{2} \mathrm{O}_{3}$, or the combination of all 3 treatments. Cytoplasmic extracts (top 2 blots) were used in immunoblotting with antiABCA1 antibody or anti- $\beta$-actin antibody. Total RNA (bottom 2 blots) was used in Northern blotting for either ABCA1 or $\beta$-actin mRNA. (B) HepG2 cells were treated with media, $50 \mu \mathrm{M}$ rifampicin, $5 \mu \mathrm{M} \mathrm{As} \mathrm{O}_{3}$, or the combination for 24 hours. Microsomes were isolated and used in immunoblotting experiments with anti-CYP3A4 antibody. Ponceau-stained band of microsomal extracts is presented as a loading control. (C) MCF-7 cells were treated with media, 10-9 M vitamin D3, $5 \mu \mathrm{M}$ $\mathrm{As}_{2} \mathrm{O}_{3}$, or the combination for 24 hours. RNA was isolated and used in Northern blotting experiments with probes for vitamin D3 24-hydroxylase (top) and $\beta$-actin (bottom). (D) NB4 cells were treated for 24 hours with $10^{-6} \mathrm{M} \mathrm{RA}, 5 \mu \mathrm{M} \mathrm{As}{ }_{2} \mathrm{O}_{3}$, or the combination. Total RNA was used in either RPAs (RAR $\beta$ ) or Northern blotting experiments (C/EBP $\varepsilon)$. $\beta$-Actin was used as a control in both RPA and Northern blot experiments.

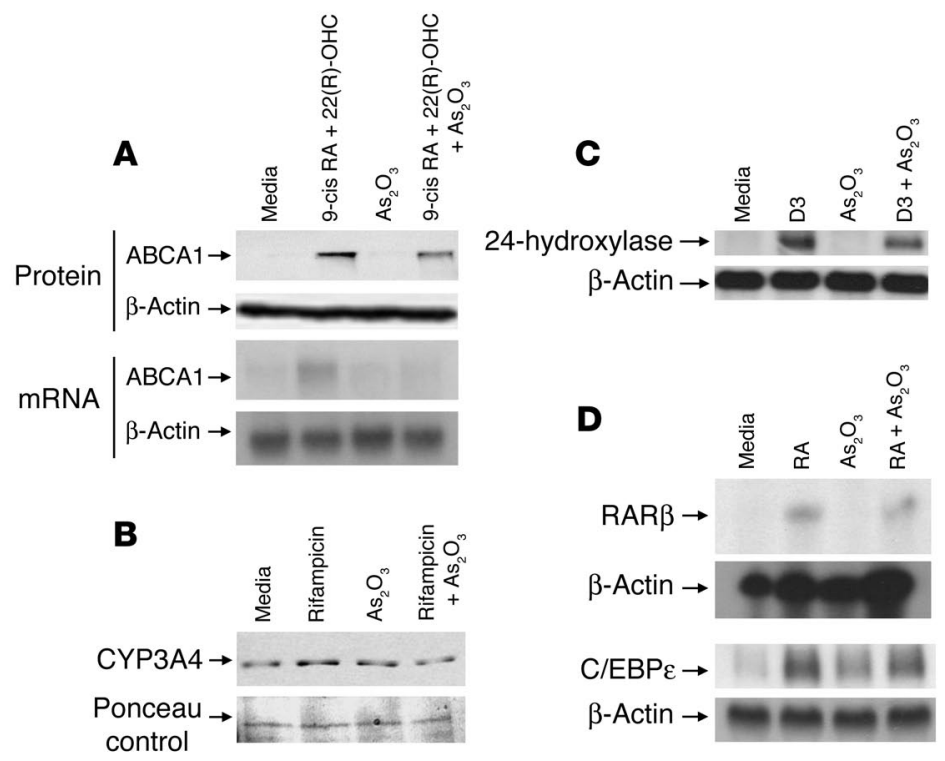


24-hydroxylase mRNA in MCF-7 breast cancer cells after 24 hours' treatment with media, $10^{-9} \mathrm{M}$ vitamin D3, $5 \mu \mathrm{M} \mathrm{As}_{2} \mathrm{O}_{3}$, or the combination. As with the other target genes, $\mathrm{As}_{2} \mathrm{O}_{3}$ cotreatment decreased the induction of 24-hydroxylase mRNA levels by vitamin D3 (Figure 7C). The expression of the classic RAR $\alpha$ target gene, RAR $\beta$, was assessed in RNase protection assays (RPAs). NB4 cells were treated for 24 hours with media, $10^{-6} \mathrm{M}$ RA, $5 \mu \mathrm{M}$ $\mathrm{As}_{2} \mathrm{O}_{3}$, or the combination. Total RNA was incubated with probes for RAR $\beta$ and $\beta$-actin. In addition, total RNA from identical treatments was used in Northern blots for C/EBPE, an RAR target gene closely associated with differentiation. RA induced C/EBPE mRNA expression, and this expression was decreased when $\mathrm{RA}$ was used in combination with $\mathrm{As}_{2} \mathrm{O}_{3}$. These data indicate that $\mathrm{As}_{2} \mathrm{O}_{3}$ exposure could have a significant impact on signaling of several nuclear receptors in a variety of cell types and that the inhibition of nuclear receptor target gene induction by $\mathrm{As}_{2} \mathrm{O}_{3}$ was not an artifact of transient transfection assays.

\section{Discussion}

Our previous data showing that $\mathrm{As}_{2} \mathrm{O}_{3}$ decreased RA-induced differentiation markers in APL cells prompted us to investigate how $\mathrm{As}_{2} \mathrm{O}_{3}$ might alter RA signaling on the molecular level. We found that $\mathrm{As}_{2} \mathrm{O}_{3}$ inhibited transactivation and gene expression by RARs as well as other nuclear receptors. Only nuclear receptors that heterodimerize with $\mathrm{RXR}$ were inhibited by $\mathrm{As}_{2} \mathrm{O}_{3}$. Therefore, we focused our investigations on how $\mathrm{As}_{2} \mathrm{O}_{3}$ might modify $\mathrm{RXR} \alpha$ to inhibit transcription from its binding partner. Previous work suggested that inhibition of RA signaling involved phosphorylation of RXR $\alpha$. Indeed, we found RXR $\alpha$ was phosphorylated in response to $\mathrm{As}_{2} \mathrm{O}_{3}$ treatment within the $\mathrm{ABC}$ domains. A role for JNK in the nuclear receptor inhibition and $\mathrm{RXR} \alpha$ phosphorylation by $\mathrm{As}_{2} \mathrm{O}_{3}$ was implicated by the use of a JNK inhibitor and cells with a deletion in SEK1, the upstream activator of JNK. Therefore, we mutated serine residues within JNK consensus phosphorylation sites in the ABC region of RXR $\alpha$. Only the mutated S32A inhibited the decrease of nuclear receptor transcriptional activity. This suggests that a novel serine target of JNK is involved in the inhibition of nuclear receptor function.

These data are reminiscent of anisomycin inhibition of RAinduced transactivation, which likely involves phosphorylation of RXR $\alpha$ on Y249 by SEK1. Here, we find that the DE domains of $\mathrm{RXR} \alpha$ are highly constitutively phosphorylated, but this level of phosphorylation is not induced upon $\mathrm{As}_{2} \mathrm{O}_{3}$ treatment. It is possible that the high level of phosphorylation within the DE domain masks a single induced phosphorylated amino acid, but we have excluded 2 serine sites suggested by previous reports. Adam-Stitah et al. reported that UV activation, as well as overexpression of JNK, leads to phosphorylation of murine $\mathrm{RXR} \alpha$ in the $\mathrm{AB}$ region (30). They defined 3 residues in the $A B$ region and 1 residue in the $\mathrm{E}$ region as targets for this inducible phosphorylation. However, they found that mutation of these amino acids did not alter the ability of 9-cis RA to induce transactivation of either a DR1 reporter or the murine RAR $\beta 2$ reporter constructs. When we mutated the corresponding serines in the human RXR $\alpha$ (S56A, S70A, and S260), we also saw no impact on the ability of RA to induce transactivation nor on the inhibition of nuclear receptor function by $\mathrm{As}_{2} \mathrm{O}_{3}$. This is further supported by a recent report showing the mutation of 3 amino acids in the AB region of RXR $\alpha$ - S61, S75, and T87 - could not inhibit RA-induced transactivation of the RAR $\beta$ promoter (31).
Both biochemical and genetic means of inhibition were used to provide evidence that $\mathrm{RXR} \alpha$ phosphorylation by $\mathrm{As}_{2} \mathrm{O}_{3}$ is JNK dependent. The use of kinase inhibitors alone could not completely rule out SEK1 as the kinase involved, since the JNK antagonist SP600125 has some activity against SEK1, albeit at a 10-fold higher $\mathrm{IC}_{50}$ than against JNK (36). Therefore, we have used MEFs deficient in both JNK1 and JNK2 to confirm the involvement of $\mathrm{JNK}$ in the response to $\mathrm{As}_{2} \mathrm{O}_{3}$. Here we show that $\mathrm{As}_{2} \mathrm{O}_{3}$ cannot inhibit VDR transactivation in JNK1/2-/- MEFs, suggesting that JNK1 or JNK2 can phosphorylate RXR $\alpha$.

We show that $\mathrm{As}_{2} \mathrm{O}_{3}$ induces phosphorylation of $\mathrm{RXR} \alpha$, but the mechanism by which this posttranslational modification facilitates nuclear receptor inhibition remains unknown. Phosphorylation may inhibit receptor signaling on several levels. The hypothesis that phosphorylation may induce a conformational change rendering RXR $\alpha$ unable to form heterodimers or bind DNA is not supported by evidence in mammalian 2-hybrid assays. In these experiments, up to $20 \mu \mathrm{M} \mathrm{As}_{2} \mathrm{O}_{3}$ did not affect the ability of RXR $\alpha$ to bind $\mathrm{T}_{3} \mathrm{R}$ (37). Phosphorylation of several nuclear receptors, such as PPAR, enhances ubiquitin-dependent degradation (38), so one might propose that RXR $\alpha$ is susceptible to degradation after phosphorylation. However, we did not see a change in total cellular RXR $\alpha$ or other nuclear receptors, as shown in Figure 3A. It is possible that RXR $\alpha$ phosphorylation affects interactions with coregulatory molecules. Hong et al. report that $\mathrm{As}_{2} \mathrm{O}_{3}(20 \mu \mathrm{M}$ dose) inhibits the interaction of silencing mediator for retinoid and thyroid hormone receptors (SMRT) with $\mathrm{T}_{3} \mathrm{R}$ and RAR, although the authors postulate that it is the phosphorylation of SMRT that interrupts the association with nuclear receptors (37). Recently, data was published associating cell death induced by a 6-[3'-(1-adamantyl)-4'-hydroxyphenyl]-2-naphthalenecarboxylic acid analog with RXR/Nurr77 translocation from the nucleus to the cytosol (39). One might hypothesize that $\mathrm{As}_{2} \mathrm{O}_{3}$-induced phosphorylation of $\mathrm{RXR} \alpha$ may trigger export from the nucleus, decreasing nuclear receptor transactivation, and perhaps participating in the mechanism by which $\mathrm{As}_{2} \mathrm{O}_{3}$ induces apoptosis. We are currently investigating this model.

Both $\mathrm{As}_{2} \mathrm{O}_{3}$ and RA are standard therapies for APL, and their combination has been suggested to increase success of achieving complete remission. The data presented here and in our previous report (1) suggest that concurrent treatment with both agents might be less effective than sequential treatment. Indeed, in SCID mice bearing NB4 cells, treatment of $8 \mathrm{mg} / \mathrm{kg} \mathrm{As}{ }_{2} \mathrm{O}_{3}$ concurrently with $10 \mathrm{mg} / \mathrm{kg}$ RA injected i.p. every second day did not impact survival time of the mice, while sequential treatment of RA followed by $\mathrm{As}_{2} \mathrm{O}_{3}$ - or $\mathrm{As}_{2} \mathrm{O}_{3}$ followed by $\mathrm{RA}$ - increased survival of the mice by $70-80 \%$ (16). However, several studies have shown that treatment of PML/RAR $\alpha$ transgenic mice or syngenic mice bearing leukemias from PML/RAR $\alpha$ transgenic mice with $\mathrm{RA}$ and $\mathrm{As}_{2} \mathrm{O}_{3}$ increases survival over treatment with either drug alone $(18,19)$. Recently, 2 reports in APL patients have shown that concurrent treatment may be more beneficial than either drug given alone (40, 41 ). Whether concurrent or sequential treatment is preferable is difficult to determine and requires further investigation.

Our data also suggest that patients treated with $\mathrm{As}_{2} \mathrm{O}_{3}$ should be carefully monitored for several parameters affected by nuclear receptor signaling. If arsenic inhibits $T_{3}$ signaling, one might expect an increase in thyroid-stimulating hormone as a compensatory mechanism. Inhibition of SXR might lead to decreased induction of CYP3A4 enzyme and decreased metabolism of 
drugs, such as coumadin or cytotoxic chemotherapeutic agents that might be combined with $\mathrm{As}_{2} \mathrm{O}_{3}$. Several nuclear receptors are involved in the control of glucose levels (PPAR, LXR), lipid levels (LXR), and calcium homeostasis (VDR). We have shown that the antagonism between $\mathrm{As}_{2} \mathrm{O}_{3}$ and nuclear receptors is not limited to APL cells, but occurs in HepG2 liver hepatoma cells, LS180 colon adenocarcinoma cells, and MCF-7 breast cancer cells as well as nonmalignant MEFs.

In addition to patients with APL, a significant human population is exposed to arsenic in the environment. $\mathrm{As}_{2} \mathrm{O}_{3}$ is clearly a carcinogen associated with skin, bladder, liver, lung, and kidney tumors (42). Exposure to $\mathrm{As}_{2} \mathrm{O}_{3}$ has been linked to atherosclerosis and diabetes $(43,44)$. The proinflammatory properties of arsenic have been proposed to play a role in the generation of atherosclerotic plaques (43). The data presented here suggest additional hypotheses. Hypercholesterolemia is also responsible for a major portion of the pathogenesis of atherosclerosis. LXR target genes are involved in cholesterol metabolism (45). Therefore, a decrease in LXR signaling by arsenic could increase serum cholesterol levels and the formation of atherosclerotic plaques. PPAR $\gamma$ agonists increase a cell's sensitivity to insulin, and many PPAR $\gamma$ target genes are involved in glucose and lipid metabolism (46). One could speculate that an $\mathrm{As}_{2} \mathrm{O}_{3}$-mediated decrease in PPAR $\gamma$ signaling would decrease insulin sensitivity. Clearly, the effects of arsenic on nuclear receptors are not limited to cancer, but in fact may have broader implications for human health.

\section{Methods}

Cells and chemicals. The NB4 APL cell line and Cos-1 cell line were grown in RPMI 1640 (Invitrogen Corp.) supplemented with 10\% FBS (Wisent Inc.). $\mathrm{SEK} 1^{+/+}$and SEK1 $1^{-/}$MEFs were a gift from J. Woodgett (University of Toronto, Toronto, Ontario, Canada) and were grown in DMEM (Invitrogen Corp.) supplemented with $10 \%$ FBS. Wild-type, SEK1/2-/- $\left(\mathrm{MKK} 4 / 7^{-/-}\right)$, and JNK1/2 $/$ MEFs were a gift from R. Davis (University of Massachusetts Medical Center, Worcester, Massachusetts, USA) (47). MCF-7 breast cancer cells and LS180 colon cancer cells were grown in MEM $\alpha$ (Invitrogen Corp.) supplemented with 10\% FBS. The JNK inhibitor SP600125, the p38 inhibitor SB203580, the MEK inhibitor PD98059, and vitamin D3 were purchased from Calbiochem. $\mathrm{As}_{2} \mathrm{O}_{3}$ was purchased from Sigma-Aldrich and used to make a $0.1 \mathrm{M}$ stock in $0.1 \mathrm{~N} \mathrm{NaOH}$ with subsequent dilutions in PBS. Ciglitazone, $\mathrm{T}_{3}$ (3,3',5-triiodo-L-thyronine), 22(R)-hydroxycholesterol, anisomycin, estradiol, RA, 9-cis RA, and dexamethasone were also purchased from Sigma-Aldrich. The RXR-specific agonist LGD-1305 was a kind gift from Ligand Pharmaceuticals Inc.

Transient transfection assay. APL cells $\left(5 \times 10^{6}\right.$ cells/transfection) were rinsed in serum-free OPTI-MEM (Invitrogen Corp.) and transfected by electroporation with $10 \mu \mathrm{g} /$ transfection of the reporter plasmid $\beta$ RE-tkCAT (48) and $5 \mu \mathrm{g} /$ transfection of phosphorylated CMV- $\beta$-gal (pCMV$\beta$-gal) as an internal control for transfection efficiency. Electroporated cells were replenished with media and grown for 48 hours in the absence or presence of drugs. CAT activity was measured using a modified protocol of the organic diffusion method as described previously (49). The CAT counts were normalized with $\beta$-gal activity to obtain the relative CAT activity.

Cos- 1 cells, LS180 cells, and MEFs were transfected using OPTI-MEM media and fugene- 6 reagent (Roche Diagnostics Corp.) at a 3:1 ratio of fugene/DNA according to the manufacturer's instructions. Cells were transfected with $2 \mu \mathrm{g}$ of receptor expression plasmid and the corresponding reporter plasmid. If the reporter plasmid was CAT or luciferase, an additional CMV- $\beta$-gal reporter plasmid was using to normalize transfection efficiency. Receptor and reporter plasmid pairs were as follows:
VDR-tk-LacZ and pSG5-VDR (gifts from J. White, McGill University), ER $\alpha$ wild-type (pSG5-HEGO) and ERE-tk-CAT (gifts from S. Mader, Université de Montréal, Montréal, Québec, Canada), pSG5-T T$_{3} R 1$ and pBLTK80 containing $80 \mathrm{bp}$ from the UCP-1 gene promoter (gifts from E. Silva, McGill University), pRC-CMV-LXR $\alpha$ and TK-LXRE(3)-Luc (gifts from J.P. Capone, McMaster University, Hamilton, Ontario, Canada), pSG5-RXR $\alpha$ and CRBPII-tk-Luc (provided by W.W. Lamph, Ligand Pharmaceuticals Inc., San Diego, California, USA), pCMX-SXR (provided by W.W. Lamph) and TKLXRE(3)-Luc (gift of R. Evans, The Salk Institute for Biological Studies, San Diego, California, USA), and PCMX-mPPAR $\gamma$ and TK-PPRE(3)-Luc (gifts from R. Evans). After 4 hours of transfection, cells were treated with the appropriate ligand. Twenty-four hours after transfection, cells were harvested and the appropriate assays performed. CAT and $\beta$-gal assays were performed as described above. Luciferase assays were performed per manufacturer's instructions using a Luciferase Assay System (Promega).

In vivo labeling. Cos-1 cells were transfected as described above with $5 \mu \mathrm{g}$ of pCMX-FLAG-RXR $\alpha$ or mutated plasmids. Eight hours after transfection, cells were switched to serum-free media overnight. After 1 hour in phosphate-free media, the media was supplemented with $50 \mathrm{mCi}\left[{ }^{32} \mathrm{P}\right]$ orthophosphate and test compounds. Three hours later, cell lysates were collected and the FLAG-tagged proteins were immunoprecipitated using M2 anti-FLAG antibody-conjugated sepharose beads (Sigma-Aldrich) overnight. After washing, immunoprecipitates were separated by $10 \%$ SDSPAGE, transferred to nitrocellulose or PVDF membrane, and exposed to film. Following detection of radiolabelled bands, membranes were used for immunoblotting with anti-FLAG antibody (Sigma-Aldrich) to control for equal immunoprecipitation and loading.

Phosphoamino acid analysis. Phosphoamino acid analysis was performed as described previously by Yang et al. (50). Briefly, ${ }^{32} \mathrm{P}$-labeled protein bands were excised from PVDF membranes resulting from in vivo labeling experiments and hydrolyzed by incubation in $6 \mathrm{~N} \mathrm{HCl}$ for 2 hours at $110^{\circ} \mathrm{C}$. The material was lyophilized and separated by electrophoresis in $\mathrm{pH} 1.9-3.5$ buffer (1:1 ratio; see ref. 51). ${ }^{32}$ P-labeled amino acids were detected by autoradiography and identified by comigration with standard phosphoamino acids that were added to each sample and detected by ninhydrin staining.

Site-directed mutagenesis. Site-directed mutagenesis was performed using a kit from Stratagene. pCMX-FLAG-RXR $\alpha$ was mutated in single amino acids using the following primers: S21A, 5'-AACTCCTCCCTCACCGCCCCGACGGGGCG-3'; S32A, 5' -ATGGCTGCCCCCGCGCTGCACCCGTCCC-3'; S36A, 5'-CCCTCGCTGCACCCGGCCCTGGGGCCTGGC-3'; S43A, 5'CCTGGCATCGGCGCCCCGGGACAGCTG-3'; S49A, 5'-GGACAGCTGCATGCTCCCATCAGCACC-3'; S56A, 5' -AGCACCCTGAGCGCCCCCATCAACGGC-3'; S70A, 5'-TCGGTCATCAGCGCCCCCCATGGGCCCCC-3'; S76A, 5'-ATGGGCCCCCACGCCATGTCGGTGCCC-3'; S91A, 5'-TTCAGCACTGGCGCCCCCCAGCTCAGC-3'; S96A, 5'-CCCCAGCTCAGCGCACCTATGAACCCC-3'; and S124A, 5'-CCCGCCCACCCCGCAGGAAACATGGC-3'. Mutagenesis was performed using the following PCR protocol: an initial denaturing step at $95^{\circ} \mathrm{C}$ for 30 seconds followed by 16 cycles of $95^{\circ} \mathrm{C}$ for 30 seconds, $55^{\circ} \mathrm{C}$ for 1 minute, and $68^{\circ} \mathrm{C}$ for 6 minutes. Original template DNA was digested with Dpn1 restriction enzyme. Mutations were confirmed by sequencing.

Microsome isolation. HepG2 cells were harvested following treatment, washed with cold PBS, resuspended in cold $0.1 \mathrm{M} \mathrm{KPO}_{4}$ buffer ( $\mathrm{pH} 7.4$ ), and homogenized using a Dounce homogenizer (KIMBLE/KONTES) for 30 strokes on ice. Lysates were centrifuged for 10 minutes at $6,000 \mathrm{~g}$ at $4^{\circ} \mathrm{C}$. Supertants were removed and centrifuged at $100,000 \mathrm{~g}$ for 90 minutes at $4-10^{\circ} \mathrm{C}$. The pellet was resuspended in Tris- $\mathrm{HCl} / \mathrm{NaCl}$ lysis buffer containing $150 \mathrm{mM} \mathrm{NaCl} ; 25 \mathrm{mM}$ Tris- $\mathrm{HCl}, \mathrm{pH}$ 8.0; $1 \%$ triton $\mathrm{X}-100 ; 1 \mu \mathrm{M}$ EDTA; $1 \mu \mathrm{M}$ orthovanadate; $1 \mu \mathrm{g} / \mathrm{ml}$ aprotinin; $10 \mu \mathrm{g} / \mathrm{ml}$ leupeptin; and $1 \mathrm{mM}$ PMSF. 
Immunoblotting. Whole-cell extracts or microsomal preparations were made in the Tris- $\mathrm{HCl} / \mathrm{NaCl}$ buffer described above. Cytoplasmic extracts were isolated from nuclear fractions using a buffer containing $10 \mathrm{mM}$ Tris, $\mathrm{pH}$ 7.8; 5 mM MgCl $2 ; 10 \mathrm{mM} \mathrm{KCl}$; $0.1 \mathrm{mM}$ EDTA; $0.3 \mathrm{M}$ sucrose; $0.5 \mathrm{mM}$ DTT; $0.5 \mathrm{mM}$ PMSF; $5 \mathrm{mM} \beta$-glycerophosphate; and $1 \mu \mathrm{g} / \mathrm{ml}$ each of aprotinin, leupeptin, and sodium orthovanadate. Cells were incubated with this buffer for 10 minutes on ice, after which $5 \mu$ l of 10\% NP-40 was added and the tube vortexed for 10 seconds. Nuclei were pelleted by centrifugation at $5,000 \mathrm{~g}$ for 1 minute, and the supernatant was saved as cytoplasmic extracts. Proteins were separated on SDS-polyacrylamide gel and transferred to nitrocellulose membrane. ABCA1 antibody (Novus Biologicals Inc.) was used at 1:500. CYP3A4 antibody (Gentest; BD Biosciences) was used at 1:3,000. The M2 anti-FLAG antibody (Sigma-Aldrich) was used at 1:1,000. RAR (sc-551; 1:500), RXR (sc-774; 1:2,000), VDR (sc-1008; 1:500), and SXR (sc-7737; 1:100) antibodies were purchased from Santa Cruz Biotechnology Inc. Primary antibodies were detected with HRP-labeled goat anti-rabbit or anti-mouse antibodies (Amersham Biosciences). Bands were detected with enhanced chemiluminescence and autoradiography.

Northern blotting. Total RNA was isolated using guanidinium thiocyanate extraction as described previously (52). Ten micrograms of total RNA were electrophoresed and transferred to Zeta-Probe membrane (Bio-Rad Laboratories). Blots were probed with ${ }^{32} \mathrm{P}$-labeled probes derived from restriction digests of plasmid DNA. Vitamin D3 24-hydroxylase plasmid was a kind gift from H. DeLuca (University of Wisconsin, Madison, Wisconsin, USA). ABCA1 probe was made by RT-PCR using the primers 5'-AGCAGATGGCCCTGGATGT-3' and 5'-AGGTCAGCTCATGCCCTATGTC3'. C/EBPE probe containing plasmid was a gift from D. Tenen (Harvard Medical School, Boston, Massachusetts, USA).

$R P A$. Total RNA was isolated as described above. RPA was performed as previously described (53). The human RAR $\beta$ riboprobe containing bases 1545-1721 cloned into pGEM4Z (Promega) and the control GAPDH ribo- probe were a kind gift from W.W. Lamph. The probes were linearized with EcoRI and radiolabeled using T7 polymerase and [ $\left.{ }^{32} \mathrm{P}\right]$-CTP (Amersham Biosciences). Hybridization of riboprobes was carried out at $50^{\circ} \mathrm{C}$ overnight, and RNase digestion was performed at $30^{\circ} \mathrm{C}$ for 1 hour with ribonuclease T1. The RNase-resistant fragments were resolved by gel electrophoresis on a $6 \%$ urea-polyacrylamide sequencing gel. Gels were dried and exposed to film.

Statistics. Results were analyzed using GraphPad Prism 4 software. Significance was determined using an analysis of variance and Bonferroni's Multiple Comparison test.

\section{Acknowledgments}

This work was supported by grants from the Canadian Institutes of Health Research (CIHR) and the Samuel Waxman Foundation (to W.H. Miller Jr.), NIH grants R01CA80686 (to J.M. Kurie) and R01CA100816-01 (to H.-Y. Lee), and American Cancer Society grant RSG-04-082-01-TBE 01 (to H.-Y. Lee). W.H. Miller, Jr., is a Chercheur National of the Fonds de la Recherche en Santé Québec (FRSQ). K.K. Mann is supported by a fellowship from the Montréal Centre for Experimental Therapeutics in Cancer/CIHR/FRSQ. The authors wish to thank Filippa Pettersson for her critical reading of this manuscript.

Received for publication October 14, 2004, and accepted in revised form July 19, 2005.

Address correspondence to: Wilson H. Miller, Jr., Lady Davis Institute for Medical Research, Sir Mortimer B. Davis Jewish General Hospital, McGill University, 3755 Cote Sainte Catherine Road, Montréal, Québec H3T 1E2, Canada. Phone: (514) 340-8222 ext. 4365; Fax: (514) 340-7573; E-mail: wmiller@ldi.jgh.mcgill.ca.
1. Shao, W., et al. 1998. Arsenic trioxide as an inducer of apoptosis and loss of PML/RAR alpha protein in acute promyelocytic leukemia cells. J. Natl. Cancer Inst. 90:124-133.

2. Chen, G.Q., et al. 1997. Use of arsenic trioxide in the treatment of acute promyelocytic leukemia (APL): I. arsenic trioxide exerts dose-dependent dual effects on APL cells. Blood. 89:3345-3353.

3. Soignet, S.L., et al. 1998. Complete remission after treatment of acute promyelocytic leukemia with arsenic trioxide. N. Engl. J. Med. 339:1341-1348.

4. Miller, W.H., Jr., et al. 1990. Novel retinoic acid receptor-alpha transcripts in acute promyelocytic leukemia responsive to all-trans-retinoic acid. J. Natl. Cancer Inst. 82:1932-1933.

5. de The, H., Chomienne, C., Lanotte, M., Degos, L., and Dejean, A. 1990. The $\mathrm{t}(15 ; 17)$ translocation of acute promyelocytic leukaemia fuses the retinoic acid receptor alpha gene to a novel transcribed locus. Nature. 347:558-561.

6. de The, H., Vivanco-Ruiz, M.M., Tiollais, P., Stunnenberg, H., and Dejean, A. 1990. Identification of a retinoic acid responsive element in the retinoic acid receptor beta gene. Nature. 343:177-180.

7. Kakizuka, A., et al. 1991. Chromosomal translocation $\mathrm{t}(15 ; 17)$ in human acute promyelocytic leukemia fuses RAR alpha with a novel putative transcription factor, PML. Cell. 66:663-674.

8. Breitman, T.R., Collins, S.J., and Keene, B.R. 1981. Terminal differentiation of human promyelocytic leukemic cells in primary culture in response to retinoic acid. Blood. 57:1000-1004

9. Gallagher, R.E., Lurie, K.J., Leavitt, R.D., and Wiernik, P.H. 1987. Effects of interferon and retinoic acid on the growth and differentiation of clonogenic leukemic cells from acute myelogenous leukemia patients treated with recombinant leu- kocyte- $\alpha$ interferon. Lenk. Res. 11:609-619.

10. Chomienne, C., et al. 1990. All-trans retinoic acid in acute promyelocytic leukemias. II. In vitro studies: structure-function relationship. Blood. 76:1710-1717

11. Huang, M.E., et al. 1988. Use of all-trans retinoic acid in the treatment of acute promyelocytic leukemia. Blood. 72:567-572.

12. Castaigne, S., et al. 1990. All-trans retinoic acid as a differentiation therapy for acute promyelocytic leukemia. I. Clinical results. Blood. 76:1704-1709.

13. Warrell, R.P., Jr., et al. 1991. Differentiation therapy of acute promyelocytic leukemia with tretinoin (alltrans-retinoic acid). N. Engl. J. Med. 324:1385-1393.

14. Degos, L., et al. 1995. All-trans-retinoic acid as a differentiating agent in the treatment of acute promyelocytic leukemia [review]. Blood. 85:2643-2653.

15. Tallman, M.S., and Rowe, J.M. 2003. Long-term follow-up and potential for cure in acute promyelocytic leukaemia. Best Pract. Res. Clin. Haematol. 16:535-543.

16. Jing, Y., et al. 2001. Combined effect of all-trans retinoic acid and arsenic trioxide in acute promyelocytic leukemia cells in vitro and in vivo. Blood. 97:264-269.

17. Gianni, M., et al. 1998. Combined arsenic and retinoic acid treatment enhances differentiation and apoptosis in arsenic-resistant NB4 cells. Blood. 91:4300-4310.

18. Rego, E.M., He, L.Z., Warrell, R.P., Jr., Wang, Z.G., and Pandolfi, P.P. 2000. Retinoic acid (RA) and $\mathrm{As}_{2} \mathrm{O}_{3}$ treatment in transgenic models of acute promyelocytic leukemia (APL) unravel the distinct nature of the leukemogenic process induced by the PML-RARalpha and PLZF-RARalpha oncoproteins. Proc. Natl. Acad. Sci. U. S. A. 97:10173-10178.

19. Lallemand-Breitenbach, V., et al. 1999. Retinoic acid and arsenic synergize to eradicate leukemic cells in a mouse model of acute promyelocytic leukemia. J. Exp. Med. 189:1043-1052.

20. Shi, Z., et al. 2003. Induction/maintenance with ATRA $/ \mathrm{As}_{2} \mathrm{O}_{3}$ combination yields a high quality clinical/molecular remission and disease-free survival in newly diagnosed patients with acute promyelocytic leukemia. Blood. 101:5328-5335.

21. Raffoux, E., et al. 2003. Combined treatment with arsenic trioxide and all-trans-retinoic acid in patients with relapsed acute promyelocytic leukemia. J. Clin. Oncol. 21:2326-2334.

22. Gronemeyer, H., Gustafsson, J.A., and Laudet, V. 2004. Principles for modulation of the nuclear receptor superfamily. Nat. Rev. Drug Discov. 3:950-964.

23. Bunone, G., Briand, P.A., Miksicek, R.J., and Picard, D. 1996. Activation of the unliganded estrogen receptor by EGF involves the MAP kinase pathway and direct phosphorylation. EMBO J. 15:2174-2183.

24. Hu, E., Kim, J.B., Sarraf, P., and Spiegelman, B.M. 1996. Inhibition of adipogenesis through MAP kinase-mediated phosphorylation of PPARgamma. Science. 274:2100-2103.

25. Rochette-Egly, C., Adam, S., Rossignol, M., Egly, J.M., and Chambon, P. 1997. Stimulation of RAR alpha activation function AF- 1 through binding to the general transcription factor TFIIH and phosphorylation by CDK7. Cell. 90:97-107.

26. Taneja, R., et al. 1997. Phosphorylation of activation functions AF- 1 and AF- 2 of RAR alpha and RAR gamma is indispensable for differentiation of F9 cells upon retinoic acid and cAMP treatment. EMBO J. 16:6452-6465.

27. Bastien, J., Adam-Stitah, S., Plassat, J.L., Chambon, P., and Rochette-Egly, C. 2002. The phosphorylation site located in the A region of retinoic $\mathrm{X}$ recep- 
tor alpha is required for the antiproliferative effect of retinoic acid (RA) and the activation of RA target genes in F9 cells. J. Biol. Chem. 277:28683-28689.

28. Solomon, C., White, J.H., and Kremer, R. 1999. Mitogen-activated protein kinase inhibits 1,25-dihydroxyvitamin D3-dependent signal transduction by phosphorylating human retinoid $\mathrm{X}$ receptor $\alpha$. J. Clin. Invest. 103:1729-1735.

29. Lee, H.-J., et al. 2000. Stress pathway activation induces phosphorylation of retinoid $\mathrm{X}$ receptor. J. Biol. Chem. 275:32193-32199.

30. Adam-Stitah, S., Penna, L., Chambon, P., and Rochette-Egly, C. 1999. Hyperphosphorylation of the retinoid $\mathrm{X}$ receptor $\alpha$ by activated c-Jun NH 2 -terminal kinases. J. Biol. Chem. 274:18932-18941.

31. Tarrade, A., et al. 2005. Retinoic acid and arsenic trioxide cooperate for apoptosis through phosphorylated RXR alpha. Oncogene. 24:2277-2288.

32. Davison, K., Mann, K.K., Waxman, S., and Miller, W.H. 2004. JNK activation is a mediator of arsenic trioxide-induced apoptosis in acute promyelocytic leukemia cells. Blood. 103:3496-3502.

33. Verma, A., et al. 2002. Activation of Rac1 and the p38 mitogen-activated protein kinase pathway in response to arsenic trioxide. J. Biol. Chem. 277:44988-44995.

34. Tournier, C., et al. 2000. Requirement of JNK for stress-induced activation of the cytochrome cmediated death pathway. Science. 288:870-874

35. Costet, P., et al. 2003. Retinoic acid receptor-mediated induction of ABCA1 in macrophages. Mol. Cell. Biol. 23:7756-7766.

36. Bennett, B.L., et al. 2001. SP600125, an anthrapyr- azolone inhibitor of Jun $\mathrm{N}$-terminal kinase. Proc. Natl. Acad. Sci. U. S. A. 98:13681-13686

37. Hong, S.H., Yang, Z., and Privalsky, M.L. 2001. Arsenic trioxide is a potent inhibitor of the interaction of SMRT corepressor with Its transcription factor partners, including the PML-retinoic acid receptor alpha oncoprotein found in human acute promyelocytic leukemia. Mol. Cell. Biol. 21:7172-7182.

38. Blanquart, C., Mansouri, R., Fruchart, J.C., Staels, B., and Glineur, C. 2004. Different ways to regulate the PPARalpha stability. Biochem. Biophys. Res. Commun. 319:663-670.

39. Lin, B., et al. 2004. Conversion of Bcl-2 from protector to killer by interaction with nuclear orphan receptor Nur77/TR3. Cell. 116:527-540.

40. Estey, E., et al. 2004. Use of all-transretinoic acid (ATRA) + arsenic trioxide (ATO) to eliminate or minimize use of chemotherapy (CT) in untreated acute promyelocytic leukemia (APL) [abstract]. Blood. 104:115a.

41. Shen, Z.X., et al. 2004. All-trans retinoic acid $/ \mathrm{As}_{2} \mathrm{O}_{3}$ combination yields a high quality remission and survival in newly diagnosed acute promyelocytic leukemia. Proc. Natl. Acad. Sci. U. S. A. 101:5328-5335.

42. Kitchin, K.T. 2001. Recent advances in arsenic carcinogenesis: modes of action, animal model systems, and methylated arsenic metabolites. Toxicol. Appl. Pharmacol. 172:249-261.

43. Simeonova, P.P., and Luster, M.I. 2004. Arsenic and atherosclerosis. Toxicol. Appl. Pharmacol. 198:444-449.

44. Tseng, C.H. 2004. The potential biological mechanisms of arsenic-induced diabetes mellitus. Toxicol.
Appl. Pharmacol. 197:67-83.

45. Steffensen, K.R., and Gustafsson, J.A. 2004. Putative metabolic effects of the liver X receptor (LXR). Diabetes. 53(Suppl. 1):S36-S42.

46. Berger, J., and Moller, D.E. 2002. The mechanisms of action of PPARs. Annu. Rev. Med. 53:409-435

47. Ventura, J.J., Cogswell, P., Flavell, R.A., Baldwin, A.S., Jr., and Davis, R.J. 2004. JNK potentiates TNFstimulated necrosis by increasing the production of cytotoxic reactive oxygen species. Genes Dev. 18:2905-2915.

48. Sucov, H.M., Murakami, K.K., and Evans, R.M. 1990 Characterization of an autoregulated response element in the mouse retinoic acid receptor type $\beta$ gene. Proc. Natl. Acad. Sci. U. S. A. 87:5392-5396.

49. Neuman, J.R., Morency, C.A., and Russian, K.O. 1987. A novel rapid assay for chloramphenicol acetyl transferase gene expression. Biotechniques. 5:444-448.

50. Yang, Y., Villain, P., Mustelin, T., and Couture, C. 2003. Critical role of Ser-520 phosphorylation for membrane recruitment and activation of the ZAP-70 tyrosine kinase in T cells. Mol. Cell. Biol. 23:7667-7677.

51. Cooper, J.A., Sefton, B.M., and Hunter, T. 1983. Detection and quantification of phosphotyrosine in proteins. Methods Enzymol. 99:387-402.

52. Chomczynski, P., and Sacchi, N. 1987. Single-step method of RNA isolation by acid guanidinium thiocyanate-phenol-chloroform extraction. Anal. Biochem. 162:156-159.

53. Zinn, K., DiMaio, D., and Maniatis, T. 1984. Identification of two distinct regulatory regions adjacent to the human $\alpha$-interferon gene. Cell. 34:865-879. 